\title{
Fernene Triterpenoids from the Lichen Pyxine berteriana
}

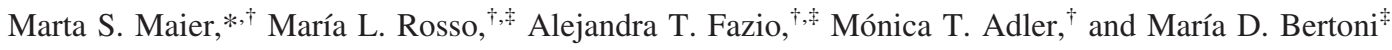 \\ UMYMFOR (CONICET-UBA) and Departamento de Química Orgánica, Facultad de Ciencias Exactas y Naturales, and \\ PROPLAME-PRHIDEB-Departamento de Biodiversidad y Biología Experimental, Facultad de Ciencias Exactas y Naturales, Pabellón 2, \\ Ciudad Universitaria, 1428 Buenos Aires, Argentina
}

Received July 22, 2009

Two new fernene triterpenoids, fern-9(11)-en-3,19-dione (1) and 3 $\beta$-acetoxyfern-9(11)-en-19-one (2), together with the known $3 \beta$-acetoxyfern-9(11)-en-19 $\beta$-ol (3) and lichexanthone (4), have been isolated from the acetone extract of the lichen Pyxine berteriana. The structures of the new compounds were established on the basis of IR, extensive 1D and 2D NMR, and MS analyses. Although several fern-9(11)-enes have been isolated from lichens, compounds $\mathbf{1}$ and 2 are the first examples of naturally occurring fernene triterpenoids with a carbonyl function at C-19.

Lichens are symbiotic associations composed of at least a fungal partner, the mycobiont, and a photosynthetic partner, the photobiont. ${ }^{1}$ These associations frequently produce characteristic secondary metabolites that are of fungal origin. Most are unique to lichens, and only a small number occur in non-lichenized fungi or higher plants. $^{2}$ Many of these lichen secondary compounds exhibit antibiotic, antitumor, antimutagenic, allergenic, antifungal, antiviral, enzyme inhibitory, and plant growth inhibitory properties. ${ }^{2,3}$ Triterpenoids are widely distributed in lichens, being commonly present in genera such as Nephroma and Pseudocyphellaria as well as in different genera of the Physciaceae (e.g., Dirinaria, Physcia, and Pyxine) and the Parmeliaceae (e.g., Parmelia and Evernia). ${ }^{3,4}$ A previous report on the secondary metabolites of Pyxine berteriana (Physciaceae) from Brazil indicated that it contained atranorin, lichexanthone, methyl pyxinate, and pyxinol, according to TLC analysis. ${ }^{4}$ In the course of the search for new metabolites from the lichen $P$. berteriana (Fée) Imshaug we have isolated two new fernene triterpenoids, fern- $9(11)$-en-3,19-dione (1) and $3 \beta$-acetoxyfern-9(11)-en-19-one (2), together with the known $3 \beta$-acetoxyfern9(11)-en-19 $\beta$-ol (3) and lichexanthone (4), which is a chemical marker of a group of species in the genus Pyxine. ${ }^{5,6}$ The structure elucidation of compounds $\mathbf{1}$ and $\mathbf{2}$ is described herein.

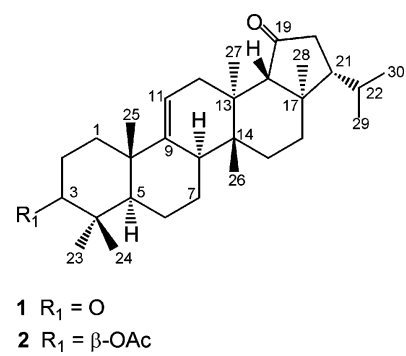

Compound 1 was obtained as a white, amorphous powder and showed a molecular ion at $\mathrm{m} / \mathrm{z} 438.3485$ in the HREIMS, indicative of a molecular formula of $\mathrm{C}_{30} \mathrm{H}_{46} \mathrm{O}_{2}$. Its IR absorption bands at 1731 and $1708 \mathrm{~cm}^{-1}$ suggested the presence of two ketone groups contained in a cyclopentanone ${ }^{7}$ and a cyclohexanone ring, ${ }^{8}$ respectively. The assignment of ${ }^{1} \mathrm{H}$ and ${ }^{13} \mathrm{C}$ NMR spectroscopic data of 1 (Table 1) was based on DEPT, HSQC, HMBC, NOESY, and ${ }^{1} \mathrm{H}-{ }^{1} \mathrm{H}$ COSY spectra. A DEPT NMR experiment permitted differentiation of the $30{ }^{13} \mathrm{C} \mathrm{NMR}$ resonances into eight methyl,

* Corresponding author. Tel and /Fax: +54 11 4576-3385. E-mail: maier@ qo.fcen.uba.ar.

UMYMFOR (CONICET-UBA) and Departamento de Química Orgánica.

${ }^{\ddagger}$ PROPLAME-PRHIDEB-Departamento de Biodiversidad y Biología Experimental. eight $\mathrm{sp}^{3}$ methylene, five $\mathrm{sp}^{3}$ methine, and five $\mathrm{sp}^{3}$ quaternary carbons, in addition to two carbonyls $\left(\delta_{\mathrm{C}} 215.4\right.$ and 216.6) and a trisubstituted vinyl group resonating at $\delta_{\mathrm{H}} 5.39$ and at $\delta_{\mathrm{C}} 117.1$ and 148.9, characteristic of a $\Delta^{9,11}$ double bond. ${ }^{9}$ Characteristic resonances in the ${ }^{1} \mathrm{H}$ and ${ }^{13} \mathrm{C}$ NMR spectra (Table 1) for six tertiary methyls $\left[\delta_{\mathrm{H} / \mathrm{C}} 0.77 / 15.6(\mathrm{C}-26), 0.91 / 15.8(\mathrm{C}-28), 0.97 / 17.0(\mathrm{C}-\right.$ 27), $1.04 / 24.3$ (C-23), 1.12/21.7 (C-24), 1.30/24.2 (C-25)] and two secondary methyls $\left[\begin{array}{llll}\delta_{\mathrm{H} / \mathrm{C}} & 0.88 / 22.8 & (\mathrm{C}-30), & 0.99 / 22.2 \\ (\mathrm{C}-29)\end{array}\right]$ indicated a fern-9(11)-ene-type pentacyclic triterpenoid skeleton. ${ }^{9}$ In accordance with the COSY spectrum, the signal at $\delta_{\mathrm{H}} 2.76(\mathrm{H}-$ $2 \beta$ ) showed cross-peaks with the signals at $\delta_{\mathrm{H}} 2.20(\mathrm{H}-1 \beta), 2.23$ $(\mathrm{H}-2 \alpha)$, and $1.64(\mathrm{H}-1 \alpha)$. On the basis of the HMBC and HSQC spectra, the signals at $\delta_{\mathrm{H}} 2.76$ and $2.23\left(\delta_{\mathrm{C}} 35.1, \mathrm{H}-2\right)$ showed crosspeaks with the signals at $\delta_{\mathrm{C}} 40.4(\mathrm{C}-1), 216.6(\mathrm{C}-3)$, and $37.6(\mathrm{C}$ $10)$, establishing that $\mathrm{C}-3$ corresponded to the carbonyl group at $\delta_{\mathrm{C}}$ 216.6. Further correlations in the HMBC spectrum of the singlet at $\delta_{\mathrm{H}} 1.30\left(\delta_{\mathrm{C}} 24.2\right)$ with the signals at $\delta_{\mathrm{C}} 37.6(\mathrm{C}-10), 40.4(\mathrm{C}-1)$, 46.4 (C-5), and 148.9 (C-9) allowed us to assign this methyl resonance to $\mathrm{C}-25$. The NOESY correlations between $\mathrm{H}-5 / \mathrm{CH}_{3}-23$ and $\mathrm{CH}_{3}-25 / \mathrm{CH}_{3}-24$ in conjunction with $\mathrm{HSQC}$ data permitted assignment of the ${ }^{1} \mathrm{H}$ and ${ }^{13} \mathrm{C}$ resonances of $\mathrm{CH}_{3}-23\left(\delta_{\mathrm{H}} 1.04, \delta_{\mathrm{C}}\right.$ 24.3) and $\mathrm{CH}_{3}-24\left(\delta_{\mathrm{H}} 1.12, \delta_{\mathrm{C}} 21.7\right)$. HMBC correlations of these methyl protons with the signal at $\delta_{\mathrm{C}} 216.6$ confirmed the assignment of this carbonyl group to $\mathrm{C}-3$. The broad doublet at $\delta_{\mathrm{H}} 2.09\left(\delta_{\mathrm{C}}\right.$ 38.8) was assigned to $\mathrm{H}-8$ on the basis of the cross-peaks with the signals at $\delta_{\mathrm{H}} 1.41$ and $1.70(\mathrm{H}-7)$ in the COSY spectrum, while correlations of the signal at $\delta_{\mathrm{H}} 2.09$ with $\mathrm{H}-5$ (1.72) and $\mathrm{CH}_{3}-27$ $\left(\delta_{\mathrm{H}} 0.97\right)$ in the NOESY spectrum confirmed its $\alpha$-orientation. We assigned the chemical shift of $\mathrm{C}-18$ at $\delta_{\mathrm{C}} 64.6$ on the basis of the HMBC correlations of $\mathrm{CH}_{3}-27\left(\delta_{\mathrm{H}} 0.97\right)$ and $\mathrm{CH}_{3}-28\left(\delta_{\mathrm{H}} 0.91\right)$ to C-18. The NOESY cross-peaks between $\mathrm{H}-18\left(\delta_{\mathrm{H}} 2.18\right)$ and $\mathrm{CH}_{3^{-}}$ $26\left(\delta_{\mathrm{H}} 0.77\right)$ showed that $\mathrm{H}-18$ had a $\beta$-orientation and indicated trans-fusion of the $\mathrm{D} / \mathrm{E}$ ring. On the other hand, $\mathrm{H}-18$ correlated in the HMBC spectrum with the signals at $\delta_{\mathrm{C}} 36.3$ (C-13), 43.0 (C-17), and the carbonyl group at $\delta_{\mathrm{C}} 215.4$. This observation together with the presence of a singlet for $\mathrm{H}-18$ in the ${ }^{1} \mathrm{H}$ NMR spectrum suggested that $\mathrm{C}-19$ corresponded to the carbonyl group at $\delta_{\mathrm{C}} 215.4$. Further HMBC correlations of $\mathrm{H}-20 \beta\left(\delta_{\mathrm{H}} 2.38\right)$ to $\mathrm{C}-17$, C-19, and C-21 confirmed the presence of a carbonyl group at C-19. On the basis of the NOESY spectrum, the signal at $\delta_{\mathrm{H}} 1.45\left(\delta_{\mathrm{C}}\right.$ $55.2, \mathrm{H}-21$ ) showed cross-peaks with $\mathrm{H}-18 \beta, \mathrm{H}-20 \beta$, and $\mathrm{CH}_{3}-26$, confirming the $\beta$-orientation of $\mathrm{H}-21$, and hence the $\alpha$-orientation of the isopropyl chain. Thus, this natural product corresponds to fern-9(11)-en-3,19-dione.

Compound 2 was obtained as a white, amorphous powder. Its HREIMS showed a molecular ion at $\mathrm{m} / \mathrm{z}, 482.3782$, indicative of a molecular formula of $\mathrm{C}_{32} \mathrm{H}_{50} \mathrm{O}_{3}$ and eight unsaturation degrees. Three of these were due to the presence of two carbonyl groups 
Table 1. NMR Spectroscopic Data $\left(500 \mathrm{MHz}, \mathrm{CDCl}_{3}\right)$ of Compounds $\mathbf{1}$ and $\mathbf{2}^{a}$

\begin{tabular}{|c|c|c|c|c|}
\hline \multirow[b]{2}{*}{ position } & \multicolumn{2}{|r|}{1} & \multicolumn{2}{|r|}{2} \\
\hline & $\delta_{\mathrm{C}}$, mult. & $\delta_{\mathrm{H}}(J$ in $\mathrm{Hz})$ & $\delta_{\mathrm{C}}$, mult. & $\delta_{\mathrm{H}}(J$ in $\mathrm{Hz})$ \\
\hline \multirow[t]{2}{*}{1} & $40.4, \mathrm{CH}_{2}$ & $1.64, \mathrm{~m}(\mathrm{H}-1 \alpha)$ & $39.0, \mathrm{CH}_{2}$ & $1.40, \mathrm{~m}(\mathrm{H}-1 \alpha)$ \\
\hline & & $2.20, \mathrm{~m}(\mathrm{H}-1 \beta)$ & & $1.93, \mathrm{dt}(13.6,3.4)(\mathrm{H}-1 \beta)$ \\
\hline \multirow[t]{2}{*}{2} & $35.1, \mathrm{CH}_{2}$ & $2.23, \mathrm{~m}(\mathrm{H}-2 \alpha)$ & 24.6, $\mathrm{CH}_{2}$ & $1.66, \mathrm{~m}$ \\
\hline & & $2.76, \operatorname{td}(14.6,5.6)(\mathrm{H}-2 \beta)$ & & \\
\hline 3 & $216.6, \mathrm{qC}$ & & $80.9, \mathrm{CH}$ & $4.48, \operatorname{dd}(9.0,6.7)$ \\
\hline 4 & $48.0, \mathrm{qC}$ & & $38.1, \mathrm{qC}$ & \\
\hline 5 & $46.4, \mathrm{CH}$ & $1.72, \mathrm{~m}$ & $44.5, \mathrm{CH}$ & $1.38, \mathrm{~m}$ \\
\hline 6 & $19.2, \mathrm{CH}_{2}$ & $1.40(\mathrm{H}-6 \alpha), 1.75(\mathrm{H}-6 \beta), \mathrm{m}$ & $18.8, \mathrm{CH}_{2}$ & $1.61,1.76, \mathrm{~m}$ \\
\hline 7 & $17.8, \mathrm{CH}_{2}$ & $1.41,1.70, \mathrm{~m}$ & $17.8, \mathrm{CH}_{2}$ & $1.27,1.63, \mathrm{~m}$ \\
\hline 8 & $38.8, \mathrm{CH}$ & 2.09, bd (13.6) & $39.0, \mathrm{CH}$ & $2.02, \mathrm{bd}$ \\
\hline 9 & $148.9, \mathrm{qC}$ & & $150.1, \mathrm{qC}$ & \\
\hline 10 & $37.6, \mathrm{qC}$ & & $37.6, \mathrm{qC}$ & \\
\hline 11 & 117.1, CH & $5.39, \mathrm{~m}$ & $116.4, \mathrm{CH}$ & $5.32, \mathrm{~m}$ \\
\hline 12 & $35.0, \mathrm{CH}_{2}$ & $2.51, \operatorname{ddd}(17.9,5.6,1.5)(\mathrm{H}-12 \alpha), 1.68, \mathrm{~m}(\mathrm{H}-12 \beta)$ & $35.1, \mathrm{CH}_{2}$ & $2.49, \operatorname{ddd}(17.8,5.4,1.8)(\mathrm{H}-12 \alpha), 1.66, \mathrm{~m}(\mathrm{H}-12 \beta)$ \\
\hline 13 & $36.3, \mathrm{qC}$ & & $36.3, \mathrm{qC}$ & \\
\hline 14 & $37.3, \mathrm{qC}$ & & $37.3, \mathrm{qC}$ & \\
\hline 15 & $28.9, \mathrm{CH}_{2}$ & $1.40, \mathrm{~m}$ & $28.9, \mathrm{CH}_{2}$ & $1.36, \mathrm{~m}$ \\
\hline 16 & $35.8, \mathrm{CH}_{2}$ & $1.65, \mathrm{~m}(\mathrm{H}-16 \beta), 1.82, \mathrm{dt}(13.2,3.4)(\mathrm{H}-16 \alpha)$ & $35.8, \mathrm{CH}_{2}$ & $1.64, \mathrm{~m}(\mathrm{H}-16 \beta), 1.83, \mathrm{dt}(13.2,3.3)(\mathrm{H}-16 \alpha)$ \\
\hline 17 & $43.0, \mathrm{qC}$ & & $43.1, \mathrm{qC}$ & \\
\hline 18 & $64.6, \mathrm{CH}$ & $2.18, \mathrm{~s}$ & $64.7, \mathrm{CH}$ & $2.17, \mathrm{~s}$ \\
\hline 19 & $215.4, \mathrm{qC}$ & & $215.5, \mathrm{qC}$ & \\
\hline 20 & $42.4, \mathrm{CH}_{2}$ & 1.77 , dd $(18.9,10.3)(\mathrm{H}-20 \alpha), 2.38, \mathrm{dd}(18.9,8.2)(\mathrm{H}-20 \beta)$ & $42.4, \mathrm{CH}_{2}$ & 1.77, dd $(18.9,10.0)(\mathrm{H}-20 \alpha), 2.38, \mathrm{dd}(18.9,8.0)(\mathrm{H}-20 \beta)$ \\
\hline 21 & $55.2, \mathrm{CH}$ & $1.45, \mathrm{~m}$ & $55.2, \mathrm{CH}$ & $1.44, \mathrm{~m}$ \\
\hline 22 & $30.2, \mathrm{CH}$ & $1.64, \mathrm{~m}$ & $30.2, \mathrm{CH}$ & $1.63, \mathrm{~m}$ \\
\hline 23 & $24.3, \mathrm{CH}_{3}$ & $1.04, \mathrm{~s}$ & $27.4, \mathrm{CH}_{3}$ & $0.84, \mathrm{~s}$ \\
\hline 24 & $21.7, \mathrm{CH}_{3}$ & $1.12, \mathrm{~s}$ & $16.1, \mathrm{CH}_{3}$ & $0.94, \mathrm{~s}$ \\
\hline 25 & $24.2, \mathrm{CH}_{3}$ & $1.30, \mathrm{~s}$ & $25.2, \mathrm{CH}_{3}$ & $1.08, \mathrm{~s}$ \\
\hline 26 & $15.6, \mathrm{CH}_{3}$ & $0.77, \mathrm{~s}$ & $15.6, \mathrm{CH}_{3}$ & $0.73, \mathrm{~s}$ \\
\hline 27 & 17.0, $\mathrm{CH}_{3}$ & $0.97, \mathrm{~s}$ & $16.9, \mathrm{CH}_{3}$ & $0.98, \mathrm{~s}$ \\
\hline 28 & $15.8, \mathrm{CH}_{3}$ & $0.91, \mathrm{~s}$ & $15.8, \mathrm{CH}_{3}$ & $0.91, \mathrm{~s}$ \\
\hline 29 & $22.2, \mathrm{CH}_{3}$ & $0.99, \mathrm{~d}(6.6)$ & $22.3, \mathrm{CH}_{3}$ & $0.98, \mathrm{~d}(6.5)$ \\
\hline 30 & $22.8, \mathrm{CH}_{3}$ & $0.88, \mathrm{~d}(6.6)$ & $22.8, \mathrm{CH}_{3}$ & $0.88, \mathrm{~d}(6.5)$ \\
\hline $\mathrm{CH}_{3} \mathrm{COO}$ & & & $170.9, \mathrm{qC}$ & \\
\hline $\mathrm{CH}_{3} \mathrm{COO}$ & & & $21.3, \mathrm{CH}_{3}$ & $2.05, \mathrm{~s}$ \\
\hline
\end{tabular}

${ }^{a}$ Assigned by a combination of ${ }^{1} \mathrm{H}-{ }^{1} \mathrm{H}$ COSY, NOESY, HSQC, and HMBC experiments.

(one band at $1732 \mathrm{~cm}^{-1}$ in the IR consistent with both a cyclopentanone ring and an ester group at $\delta_{\mathrm{C}} 170.9$ and 215.5 in the ${ }^{13} \mathrm{C}$ NMR spectrum) and one trisubstituted double bond $\left[\delta_{\mathrm{H}}\right.$ 5.32 and $\delta_{\mathrm{C}} 116.4$ and 150.1]. The assignment of ${ }^{1} \mathrm{H}$ and ${ }^{13} \mathrm{C} \mathrm{NMR}$ spectroscopic data of 2 (Table 1) was based on DEPT, HSQC, HMBC, NOESY, and ${ }^{1} \mathrm{H}-{ }^{1} \mathrm{H}$ COSY spectra. The ${ }^{13} \mathrm{C}$ NMR spectrum showed 32 resonances, of which 30 were attributed to a fern-9(11)-ene-type pentacyclic triterpene skeleton and two to an acetyl group $\left(\delta_{\mathrm{H}} 2.05 ; \delta_{\mathrm{C}} 21.3\right.$ and 170.9). ${ }^{9}$ A DEPT NMR experiment showed the presence of nine methyl, eight $\mathrm{sp}^{3}$ methylene, six $\mathrm{sp}^{3}$ methine (one oxygenated), and five $\mathrm{sp}^{3}$ quaternary carbons, in addition to the carbonyl and olefinic carbons. Analysis of the ${ }^{13} \mathrm{C}$ NMR spectroscopic data of $\mathbf{2}$ (Table 1) revealed structural similarity to those of $3 \beta$-acetoxyfern-9(11)-en-19 $\beta$-ol (3), ${ }^{9}$ except for the presence of a ketone functionality $(\delta 215.5 \mathrm{ppm})$ and the absence of the hydroxy group at C-19 $\left(\delta_{\mathrm{C}} 71.2 \mathrm{ppm}, \delta_{\mathrm{H}} 4.23 \mathrm{ppm}\right)$. This observation, along with the HMBC correlations from $\mathrm{H}-18$ $\left(\delta_{\mathrm{H}} 2.17\right)$ to $\mathrm{C}-13, \mathrm{C}-17, \mathrm{C}-28$, and the carbonyl signal at $\delta_{\mathrm{C}} 215.5$, indicated the presence of a $\mathrm{C}-19$ ketone functionality. Further HMBC correlations from $\mathrm{H}-20$ to $\mathrm{C}-17, \mathrm{C}-21, \mathrm{C}-22$, and the signal at $\delta_{\mathrm{C}} 215.5$ together with comparison of ${ }^{1} \mathrm{H}$ and ${ }^{13} \mathrm{C}$ NMR data of $\mathbf{2}$ with those of rings $\mathrm{C}, \mathrm{D}$, and $\mathrm{E}$ of compound $\mathbf{1}$ confirmed that both compounds shared the same ketone functionality at C-19 and differed in the substituent at C-3. The NMR data of compound 2 showed close resemblance with those of rings $\mathrm{A}$ and $\mathrm{B}$ and $\mathrm{CH}_{3^{-}}$ 23, $\mathrm{CH}_{3}-24$, and $\mathrm{CH}_{3}-25$ of $3 \beta$-acetoxyfern-9(11)-en- $19 \beta$-ol (3). ${ }^{9}$ On the basis of the HMBC and HSQC spectra, the signals at $\delta_{\mathrm{H}}$ 1.40 and $1.93\left(\delta_{\mathrm{C}} 39.0, \mathrm{H}-1\right)$ showed cross-peaks with the signals at $\delta_{\mathrm{C}} 24.6(\mathrm{C}-2), 25.2\left(\mathrm{CH}_{3}-25\right), 37.6(\mathrm{C}-10)$, and $44.5(\mathrm{C}-5)$, whereas the signal at $\delta_{\mathrm{H}} 4.48\left(\delta_{\mathrm{C}} 80.9, \mathrm{H}-3\right)$ correlated with the signals at $\delta_{\mathrm{C}} 16.1\left(\mathrm{CH}_{3}-24\right), 24.6(\mathrm{C}-2), 27.4\left(\mathrm{CH}_{3}-23\right)$, and 38.1 (C-4). These data together with the HMBC correlations of the methyl singlet at $\delta_{\mathrm{H}} 2.05\left(\delta_{\mathrm{C}} 21.3, \mathrm{CH}_{3} \mathrm{COO}\right)$ with $\delta_{\mathrm{C}} 80.9(\mathrm{C}-3)$ and $170.9\left(\mathrm{CH}_{3} \mathrm{COO}\right)$ established the position of the acetoxy group at C-3. NOESY correlations between $\mathrm{H}-3$ and $\delta_{\mathrm{H}} 0.84\left(\mathrm{CH}_{3}-23\right)$, $1.38(\mathrm{H}-5 \alpha)$, and $1.40(\mathrm{H}-1 \alpha)$ confirmed the $\beta$-orientation of the acetoxy group. The NOESY cross-peaks between $\mathrm{H}-5 / \mathrm{CH}_{3}-23$ and $\mathrm{CH}_{3}-25 / \mathrm{CH}_{3}-24$ in conjunction with $\mathrm{HSQC}$ data allowed assignment of the ${ }^{1} \mathrm{H}$ and ${ }^{13} \mathrm{C}$ NMR resonances of $\mathrm{CH}_{3}-23\left(\delta_{\mathrm{H}} 0.84, \delta_{\mathrm{C}} 27.4\right)$, $\mathrm{CH}_{3}-24\left(\delta_{\mathrm{H}} 0.94, \delta_{\mathrm{C}} 16.1\right)$, and $\mathrm{CH}_{3}-25\left(\delta_{\mathrm{H}} 1.08, \delta_{\mathrm{C}} 25.2\right)$. As a consequence, compound 2 is identified as $3 \beta$-acetoxyfern-9(11)en-19-one.

Compounds $\mathbf{1}$ and $\mathbf{2}$ are the first naturally occurring examples of fernene-type triterpenoids containing an unprecedented ketone function at C-19. Previously, two semisynthetic derivatives with a carbonyl group at C-19, fern-9(11)-en-19-one and fern-7-en-19one, were obtained by $\mathrm{CrO}_{3}$ oxidation of two fernene triterpenoids isolated from the rhizomes of Davallia solida. ${ }^{7}$ Compound $\mathbf{1}$ is the second example of a natural fernene-type triterpenoid with two ketone groups. Previously, fern-9(11)-en-3,12-dione has been isolated from the lichen Xanthoria resendei. ${ }^{8}$

Compound 3 was isolated as a white, amorphous powder and identified as $3 \beta$-acetoxyfern-9(11)-en-19 $\beta$-ol by comparison of the NMR and EIMS data with those reported previously. ${ }^{9}$ Lichexanthone (4) was isolated as a yellow, amorphous powder and identified by EIMS and ${ }^{1} \mathrm{H}$ NMR data and comparison with published data. ${ }^{3}$

\section{Experimental Section}

General Experimental Procedures. Optical rotations were measured on a Perkin-Elmer 343 polarimeter. IR spectra were recorded on a Nicolet Magna-550 FT-IR spectrometer. ${ }^{1} \mathrm{H}$ and ${ }^{13} \mathrm{C}$ NMR spectra were recorded in $\mathrm{CDCl}_{3}$ on a Bruker AM 500 spectrometer. EIMS data were recorded on a Shimadzu QP-5000 mass spectrometer. HREIMS were obtained on a VG ZAB T4 mass spectrometer. Analytical HPLC was carried out on a Gilson 506C HPLC chromatograph using a reversed-phase analytical column (Phenomenex Hypersil; $5 \mu \mathrm{m}$ pore size, $250 \times 4.6 \mathrm{~mm}$ ). The samples were eluted with a two-solvent

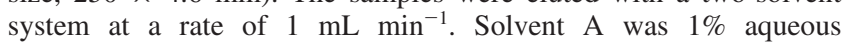


orthophosphoric acid- $\mathrm{MeOH}$ (7:3), and solvent $\mathrm{B}$ was $\mathrm{MeOH}$. The gradient started with $0 \% \mathrm{~B}$ and increased to $58 \% \mathrm{~B}$ within $15 \mathrm{~min}$, then to $100 \%$ B within $15 \mathrm{~min}$, followed by $100 \% \mathrm{~B}$ for $10 \mathrm{~min}$. Compounds were detected using a 170 photodiode array detector set at $245 \mathrm{~nm}$, operated in series with Unipoint System software, recording the absorption spectrum in the range $200-400 \mathrm{~nm}$. TLC was performed on precoated Si gel F254 (cyclohexane-EtOAc (9:1)) and detected by spraying with $\mathrm{H}_{2} \mathrm{SO}_{4}(5 \% \mathrm{EtOH})$.

Lichen Material. Thalli of $P$. berteriana were collected on $M$. azedarach by one of the authors (M.T.A.) at Glew, Buenos Aires Province, Argentina, on October 7, 2000. A voucher specimen (39315) was identified by M.T.A. and preserved at the Herbarium of the Faculty of Exact and Natural Sciences (BAFC), Buenos Aires, Argentina.

Extraction and Isolation. The lichen (1.05 g wet weight) was cleaned, cut into small pieces, and extracted in acetone $(100 \mathrm{~mL})$ at room temperature. The acetone extract was evaporated under reduced pressure to give a residue $(103 \mathrm{mg})$, which was subjected to silica gel column chromatography using cyclohexane and cyclohexane-EtOAc mixtures (99:1 and 98:2) as eluents to give the pure triterpenoids 1 $(8.0 \mathrm{mg}), \mathbf{2}(3.6 \mathrm{mg})$, and $\mathbf{3}(2.9 \mathrm{mg})$ and lichexanthone (4) $(14.6 \mathrm{mg})$. Compounds 1 and 2 showed one peak in their HPLC chromatograms at $t_{\mathrm{R}} 41.4$ and $37.5 \mathrm{~min}$, respectively.

Fern-9(11)-en-3,19-dione (1): white, amorphous powder; $[\alpha]^{20}{ }_{D}$ -9.3 (c 0.33, $\mathrm{CHCl}_{3}$ ); IR (KBr) $v_{\max } 2964,2936,2669,1731,1708$ $1469,1382,1110 \mathrm{~cm}^{-1} ;{ }^{1} \mathrm{H}$ and ${ }^{13} \mathrm{C}$ NMR data, see Table 1; EIMS $\mathrm{m} / z$ $438[\mathrm{M}]^{+}, 423,405$; HREIMS $\mathrm{m} / \mathrm{z}, 438.3485$ (calcd for $\mathrm{C}_{30} \mathrm{H}_{46} \mathrm{O}_{2}$, 438.3498)

3及-Acetoxyfern-9(11)-en-19-one (2): white, amorphous powder; $[\alpha]^{20}+6.7\left(c\right.$ 0.15, $\left.\mathrm{CHCl}_{3}\right)$; IR (KBr) $v_{\max } 2948,2854,1732,1451$, 1376, 1246, $1027 \mathrm{~cm}^{-1} ;{ }^{1} \mathrm{H}$ and ${ }^{13} \mathrm{C}$ NMR data, see Table 1; EIMS $\mathrm{m} / \mathrm{z}$ $482[\mathrm{M}]^{+}, 467,407$; HREIMS $\mathrm{m} / \mathrm{z}, 482.3782$ (calcd for $\mathrm{C}_{32} \mathrm{H}_{50} \mathrm{O}_{3}$, $482.3760)$
Acknowledgment. This work was supported by the University of Buenos Aires (Grant X124) and CONICET (PIP 5509). Mass spectrometry was provided by the Washington University Mass Spectrometry Resource, an NIH Research Resource (Grant No. P41RR0954). M.A.F. thanks the University of Buenos Aires for a Doctoral fellowship. M.S.M. and M.T.A. are Research Members of the National Research Council of Argentina (CONICET).

Supporting Information Available: Spectroscopic data of new compounds $\mathbf{1}$ and $\mathbf{2}$. This material is available free of charge via the Internet at http://pubs.acs.org.

\section{References and Notes}

(1) Nash, T. H., III. In Lichen Biology; Nash, T. H., III, Ed.; Cambridge University Press: New York, 1996; Chapter 1, pp 1-7.

(2) Elix, J. A. In Lichen Biology; Nash, T. H., III, Ed.; Cambridge University Press: New York, 1996; Chapter 9, pp 176-178.

(3) Huneck, S.; Yoshimura, I. Identification of Lichen Substances; Springer Verlag: Berlin, 1996; pp 208-209.

(4) Huneck, S.; Morales Mendez, A.; Kalb, K. J. Hattori Bot. Lab. 1987, $62,331-338$.

(5) Kathirgamanathar, S.; Ratnasooriya, W. D.; Baekstrom, P.; Andersen, R. J.; Karunaratne, V. Pharm. Biol. 2006, 44, 217-220.

(6) Kalb, K. Brasilianische Flechten. 1. Die Gattung Pyxine, Bibliotheca Lichenologica, Band 24; J. Cramer: Stuttgart, 1987; pp 20-21.

(7) Tanaka, Y.; Kitajima, J.; Ageta, H. Nat. Med. 1998, 52, 409-413.

(8) González, A. G.; Martín, J. D.; Pérez, C. Phytochemistry 1974, 13, $1547-1549$.

(9) Wilkins, A. L.; Elix, J. A. Aust. J. Chem. 1990, 43, 623-627.

NP900442Y 